\title{
Tanulmányok
}

\section{A PATOLÓGIAI DIAGNOSZTIKA HELYZETE, PROBLÉMÁI ÉS FEJLESZTÉSI LEHETŐSÉGEI}

\section{THE SITUATION AND PROBLEMS OF PATHOLOGY DIAGNOSTICS AND POSSIBILITIES FOR DEVELOPMENT}

\author{
Tímár József \\ az MTA doktora, egyetemi tanár \\ Egészségügyi Szakmai Kollégium Patológiai Tagozat, Semmelweis Egyetem, 2. sz. Patológiai Intézet, Budapest \\ jtimar@gmail.com
}

\begin{abstract}
ÖSSZEFOGLALÁS
A patológiai diagnosztika, bár kis szakmának tekintik, központi szerepet tölt be a betegellátásban, különösen azon betegségek esetén ahol a diagnózishoz és a kezelések megtervezéséhez szövettani vizsgálatra van szükség. A jelenlegi patológiai szolgáltatási igények alapján hazánkban csaknem hétszáz patológusra volna szükség, aminek csak kevesebb mint a fele áll rendelkezésre. A szükséges szakemberlétszám fejlesztése a jelenlegi rezidenslétszámokkal nem valósítható meg. A jelenlegi hazai patológiai osztályok 40\%-ában nincsenek biztosítva a szakember munkájához szükséges minimumfeltételek. Ugyanakkor a patológiai osztályok infrastruktúrája is elavult, az újabb fejlesztések elsősorban az ország fejlődő régióit érintették. Mindezek következményeként az ún. leletátfordulási idő sokkal hosszabb az elvárhatónál. A fenti problémát fokozza, hogy a jogszabályban megkövetelt szövettani vagy molekuláris patológiai vizsgálatok finanszírozása nem TVK- (teljesítményvolumen-korlát) mentes, és több olyan szolgáltatás is van, melynek még TVK-ja sincsen. Ehhez képest csodának tekinthető, hogy a hazai patológia, elsősorban a kiváló egyetemi patológiai intézetek révén, nemzetközileg elismert, kiemelkedően sikeres kutatásokat folytat, és nagyon erős publikációs aktivitást mutat évtizedek óta. A jelenlegi kritikus helyzetből a kitörés csak szisztematikus szakemberképzéssel, a digitális patológiai technológiák széles körű bevezetésével, a finanszírozás racionalizálásával és észszerű centralizációval lehetséges.
\end{abstract}

\section{ABSTRACT}

Pathology plays a central role in the management of diseases where diagnostics and/or treatment decisions require tissue-based histological evaluation. Based on the medical demand in Hungary pathology departments should employ about 700 specialists compared to the actual half-sized fleet. As a result, $40 \%$ of the pathological departments don't have the minimally 
required number of specialists. On the other hand, the infrastructure is mostly obsolete, and the new expansions are focused on developing regions leaving the central region behind. These problems are also intensified by the problems of the reimbursement schemes. As a consequence the turn-around time of pathological diagnoses is unacceptably long. Meanwhile, the international recognition of Hungarian pathology is high, mostly due to the university pathology departments, their successful translational research and their large number of high impact publications. The improvement of this situation can only be expected from the systematic and continuous human resources development, establishment of digital pathology networks, improvement of reimbursement schemes and a rational centralization.

Kulcsszavak: patológiai diagnosztika, szakemberhiány, finanszírozás, fejlesztés

Keywords: surgical pathology, human resource crisis, reimbursement, development

\section{BEVEZETŐ}

A betegségek patológiai diagnosztikája sokat fejlődött az elmúlt évszázadban. Bár fundamentális alapjai - a betegségek szövettani klasszifikációja - nem változtak (formalinfixált paraffinba ágyazott szövetekből készült metszeteken folytatott fénymikroszkópos diagnosztika), ezek sokat finomodtak a citokémia, az elektronmikroszkópia és az immunhisztokémia módszereinek felhasználása révén. Az új évezredben azonban forradalmi változások történtek az orvostudomány legkonzervatívabbnak tartott területén. A molekuláris genetikai technológiák felhasználásával fény derült például arra, hogy a szövettanilag eltérő daganatok genetikailag is különböznek egymástól, de ami még ennél is fontosabb, hogy a szövettanilag megkülönböztethetetlen daganatok molekuláris genetikai alapon tovább osztályozhatók. Ez tette lehetővé a daganatok molekuláris klaszszifikációjának kidolgozását, és általánosságban a molekuláris patológiai diagnosztika kialakulását. Bár sokan ebben már azt látják, hogy ezzel megtörtént a patológiai/szövettani klasszifikációk trónfosztása, a mértékadó véleményformálók felhívják rá a figyelmet, hogy a kétféle felosztásnak együttesen van biológiai és klinikai értelme.

A patológia fejlődése azonban új utakra vezette ezt a szakmát. Az elmúlt néhány évtizedben kialakult az ún. prognosztikus patológia, amely túllép a differenciáldiagnosztikán (az ún. „végső diagnózison”), és a beteg szövetmintájának különféle sajátosságai alapján megkísérli megbecsülni a betegség lehetséges kimenetelét is. Ezzel párhuzamosan kialakult az ún. prediktív patológia is. Ugyanis a daganatok molekuláris klasszifikációja segítségével sikerült azonosítani a legtöbb gyakori vagy ritka daganatban az ún. molekuláris drivereket (irányítókat), melyek kulcsszerepet töltenek be ezen daganatok életében, és amelyek 
az új típusú, ún. célzott terápiák célpontjai lehetnek. Így bővült a klasszikus kemoterápia a molekulárisan célzott gyógyszerek körével. Amíg azonban a klaszszikus kemoterápia alkalmazásához elegendőnek bizonyult a patológiai/szövettani diagnózis, addig ezen új, célzott terápiás szerek alkalmazásához szükséges az általuk megcélzott genetikai hiba kimutatása a daganatokban. A daganatok diagnosztikája klasszikusan a sebészi mintavételből/mütétből származó anyagokon alapult, és a molekuláris diagnosztika eszköztárának bevetését a patológusra bízta a pontosabb diagnózis érdekében. Ugyanakkor a célzott terápiás szerek alkalmazásáról végső soron a daganatos beteget ellátó, a terápiás döntést hozó klinikus dönt, ezért ő kéri meg azon genetikai hibák vizsgálatát, amelyek az adott daganatféleségben lehetséges gyógyszercélpontok. Ezzel alakult ki a prediktív molekuláris diagnosztika, amely tehát arra szolgál, hogy választ adjon arra a kérdésre, hogy egy adott génhibára törzskönyvezett gyógyszer alkalmazásának feltételei a beteg daganatában fennállnak-e.

Együttesen ezek a fejlemények tovább erősítették a patológia központi szerepét a betegellátásban, és számos betegség esetében (mint például a daganatos betegségek) megkerülhetetlen főszereplővé tették. Mindezen fejlemények jelentőségét tekintetbe véve érdemes elemezni a hazai patológiai diagnosztika helyzetét, problémáit és a lehetséges megoldási lehetőségeket.

\section{A HAZAI PATOLÓGIAI SZOLGÁLTATÁSOK VOLUMENE ÉS FORMÁI}

Évente hazánkban nagyságrendileg mintegy egymillió alkalommal vesznek szövettani mintát betegből, melyeken az egészségügyi törvény alapján kötelező patológiai vizsgálatot végezni (1. táblázat). Az elmúlt évtizedekben a szövettani mintavétel mellett egyre kiterjedtebb lett a citológiai diagnosztika alkalmazása, elsősorban a méhnyakrákszürés miatt, ami sok százezer ilyen típusú vizsgálatot jelent évente. Ugyanakkor ezt a technikát igen jól lehet hasznosítani a különféle képalkotókkal vezérelt diagnosztika pontosítására is, ez az ún. aspirációs citológiai diagnosztika, melyet hazánkban jelentős számban csak néhány jól felszerelt centrumban végeznek. Végül igazi hungarikum, hogy a kórházban elhunytak esetében és a területi elhalálozások közül azokban, ahol tisztázatlan a halál oka, boncolást kell végezni. Ez évi közel negyvenezer boncolást jelent, az összes elhalálozás közel felét. Ennek eredményeként a hazai halálozási okokra vonatkozó statisztikai adatok igen megbízhatóak, szemben azokkal az országokkal, amelyekben az ún. boncolási arány alacsonyabb vagy elenyésző. Ennek azonban az az ára, hogy ez a feladat nagymértékben terheli a patológiai szolgáltatókat, és jelentős költséget okoz az egészségbiztosító számára is. Az egész magyarországi patológiai diagnosztika problémája, hogy hasonlóan a más úton nyert diagnózisokhoz (képalkotó, labordiagnosztika etc.) a szövettani/citológiai leleteket is 
a $\mathrm{BNO}^{1}$-rendszer szerint kódolják, ami teljesen irrelevánssá vált a patológiában, mivel az évtizedek óta alapvetően a SNOMED ${ }^{2}$-rendszert alkalmazza, mely a $\mathrm{WHO}^{3}$ irányelvei szerint a hisztopatológiai eltérések azonosításának alapja. Nagy szükség lenne arra, hogy a hazai szövettani/citológiai leletek a SNOMED szerint legyenek kódolva, és ezeket a patológiai diagnózisokat ismerje az egészségbiztosító. Ennek az lenne az előnye, hogy pontosabb képet kapna a betegségekről, a releváns terápiákat jobban össze lehetne kapcsolni a diagnózisokkal, és végül, de nem utolsósorban, sokkal pontosabb képet lehetne kapni az egyes betegségek, föleg a daganatos betegségek hazai epidemiológiájáról, ami egyszerüsítené és pontosítaná például a Nemzeti Rákregiszter munkáját is.

1. táblázat. Hazai patológiai beavatkozások évi nagyságrendje

\begin{tabular}{|l|c|}
\hline \multicolumn{1}{|c|}{ Tevékenység típusa } & Száma \\
\hline kórszövettan & 1000000 \\
\hline nőgyógyászati citológia & 350000 \\
\hline aspirációs citológia & 45000 \\
\hline kórboncolás & 35000 \\
\hline molekuláris patológia & 20000 \\
\hline
\end{tabular}

Végül a 21. századra megjelent a megfelelő infrastruktúrával és személyi állománnyal rendelkező III. szintủ szolgáltatás, a molekuláris patológia - ennek diagnosztikai igénye évi 20000 eset lehet. Ma döntő része az ún. terápiához kötött prediktív molekuláris patológiai diagnosztika, és hat centrum látja el (a négy orvosegyetem öt intézete és az Országos Onkológiai Intézet). Jellemzően ennek megbecslése is nehéz, mert ún. diagnózisspecifikus molekuláris patológiai $\mathrm{OENO}^{4}$ - vagy BNO-kódok jelenleg nincsenek.

A fenti szakmai feladatokat a Magyar Patológusok Társasága (MPT) 2012-es felmérése szerint (dr. Matolcsy András elnök) 270 patológus szakorvos látja el, közülük közel hatvanan nyugdíjasok (>20\%). Ugyanakkor a nemzetközi ajánlásoknak megfelelően szakorvosonként évi 3500 patológiai lelettel számolva, közel hétszáz szakorvosra lenne szükség. Ez azt jelenti hogy a szükséges kontingens $40 \%$-a áll csak rendelkezésre. A minimumfeltételek szerint egy patológiai osztály három szakorvosból áll. A hazai hatvanhárom patológiai osztály esetében egyet-

\footnotetext{
${ }^{1}$ A BNO a betegségek nemzetközi osztályozására szolgáló kódrendszer rövidítése.

${ }^{2}$ SNOMED - Systemtized Nomenclature of Medicine.

${ }^{3} \mathrm{WHO}$ - World Health Orginization (Egészségügyi Világszervezet).

${ }^{4}$ OENO - Orvosi Eljárások Nemzetközi Osztályozása.
} 
len olyan szolgáltató van (Országos Onkológiai Intézet) mely teljesíti ezt a minimumfeltételt (1. ábra). Ennek következtében az egyetemi patológiák esetében 1,7-szeres, a nem egyetemi patológiákon háromszoros a szakorvosok túlterheltsége. Természetesen az egyetemi patológiákon még további jelentős munkaterhelést okoznak a nagyfokú oktatási (és nem utolsósorban a kutatási) terhek is. A hatvanhárom szolgáltató közül huszonöt ( 40\%) esetében kritikus a helyzet, mert csak egy föállású szakorvos dolgozik, ami veszélyezteti a kórház müködését is. Ez az arány megdöbbentően magas.

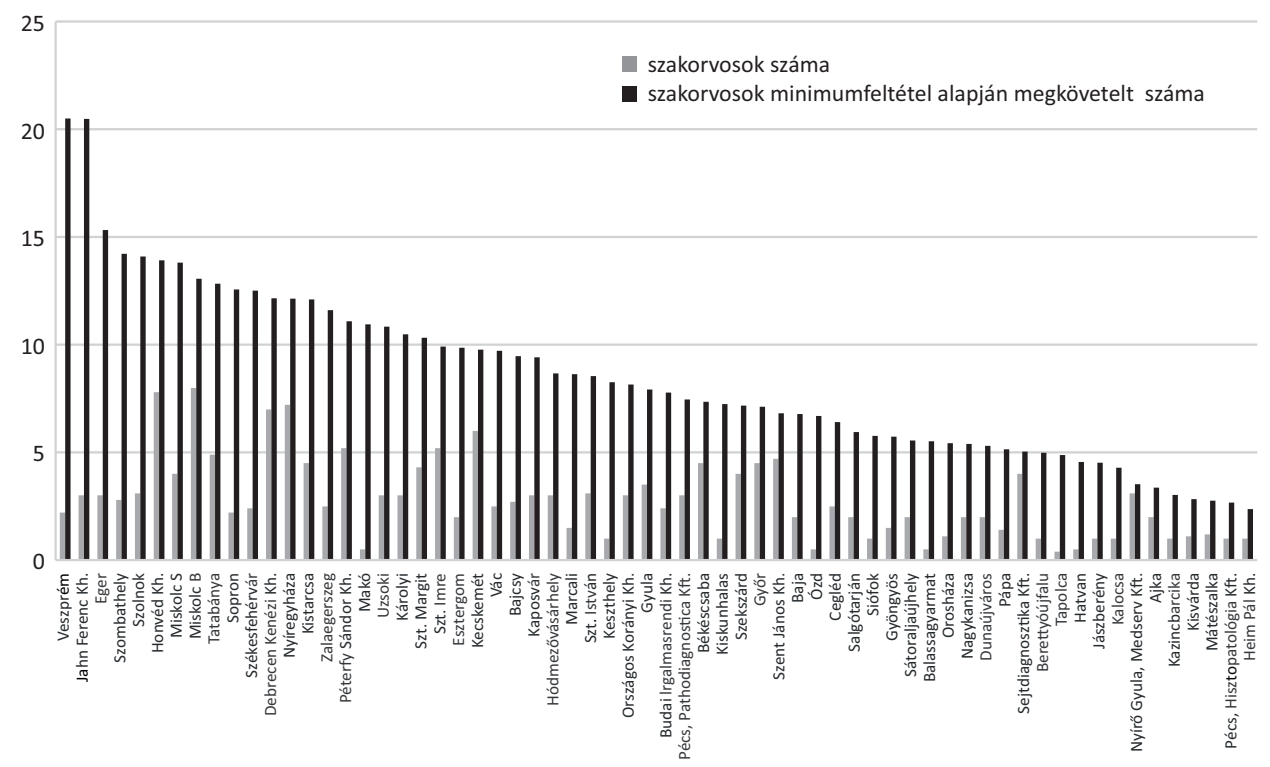

1. ábra. A hazai patológiai osztályok szakorvos-ellátottsága a minimumfeltételekhez viszonyítva 2012-ben (az MPT adatai alapján saját szerkesztés)

Ezekkel a gondokkal kapcsolatban felmerül a patológus utánpótlás helyzete is. Hazánkban jelenleg közel ötven szakorvosjelölt dolgozik a képzőhelyeken, és évente tíz-tizenöten tesznek szakvizsgát. Ez az arány arra elegendő, hogy a szakorvosok évi kiesését (elhalálozását, szakmaelhagyását, külföldre távozását) pótolja, de arra teljességgel alkalmatlan, hogy a fenti, nagyon kedvezötlen patológushiányt érdemben csökkentse. Korábban a patológus hiányszakma volt, mára azonban már számos más szakterület is csatlakozott ehhez a körhöz, és a figyelem egyre inkább más szakmákra terelődik. A rezidensi juttatások jelentős emelése mindenesetre pozitív fordulatot hozott, ami azonban a szükségleteket messze nem tudja kielégíteni.

A fenti humánerőforrás-krízis azonban infrastrukturális krízissel is társul, miután tíz éve nem volt átfogó fejlesztési program. Ezt ismerte fel az egészségügyi 
kormányzat, és indított fejlesztést a GINOP ${ }^{5}$-program keretében tizenöt-húsz fejlődő régiós szolgáltatónál, és elkezdődött a $\mathrm{VEKOP}^{6}$-program keretében a központi régió szolgáltatóinak fejlesztése. Ezzel a fejlesztéssel az a gond, hogy jelenleg harminchárom ún. onkológiai ellátó hely van, amelyek ún. patológiai szolgáltatási igényei megkérdőjelezhetetlenek, így a fejlesztés ezeket jobb helyzetbe hozhatja, miközben lemond a szolgáltatók másik feléröl. Ide sorolódnak a hazai patológiai ellátás csúcsintézményei is, valamennyi III. szintủ patológiai centrum. Másrészt, az infrastrukturális fejlesztés személyi feltételek biztosítására is tekintettel kellene hogy legyen, ellenkező esetben a szolgáltatás minősége és sebessége nem fog változni. Mindezen problémák következménye az, hogy a patológiai lelet átfutási ideje elfogadhatatlanul hosszú a II. szinteken (2-6 hét), de a III. szinteken sem éri el a nemzetközi standardot (3-4 nap), inkább annak kétszerese.

Egy újabb hatalmas kihívás a patológia mint egészségre veszélyes technológia azonosítása. Az Európai Unióban a patológiában általánosan használt formalin első fokú karcinogén besorolást kapott, az ennek megfelelő munkavédelmi követelmények kötelező megteremtésével. Jelenleg sehol a világon nem lehet a patológiában a formalin használatát mellőzni, mert nincsen alternatív technológia, így az egyetlen lehetséges megoldás a biztonságos munkahelyi környezet megteremtése. A hazai patológiák igen kis hányada felel meg a szigorú munkavédelmi követelményeknek. Égetően szükséges ezt a problémát kiemelt jelentőségủ ágazati kérdéssé emelni, és rendszerszinten megoldani, ami a patológiai osztályok megfelelő infrastrukturális fejlesztése útján valósítható csak meg, erre viszont a jelenlegi GINOP- és VEKOP-programok nem alkalmasak.

\section{A PATOLÓGIAI DIAGNOSZTIKA FINANSZÍROZÁSA ÉS ANNAK PROBLÉMÁI}

Mint az egészségügyi szolgáltatások döntö többségét, a patológiai diagnosztikát is a teljesítményvolumen-korlát (TVK) alkalmazásával finanszírozzák. Ez szembe megy azzal a törvényi kötelezettséggel, hogy minden emberből kivett szövetet patológiai vizsgálatnak kell alávetni. A jelenlegi rendszer ismeri és alkalmazza ezt az elvet, mert a kórboncolások esetében elismeri, hogy amennyiben törvényi kötelezettség a boncolás, akkor arra nem érvényes a TVK elve. A kórszövettan és a boncolások finanszírozási elvei közötti nyomasztó ellentétet a patológiai diagnosztika TVK mentesítésével kellene feloldani. További probléma, hogy a szakrendelői ellátásnak nincsen patológiai TVK-ja (még kerete sem), így ez a területi ellátási kötelezettséggel kijelölt patológiai szolgáltatókat sújtja. További súlyos probléma, hogy jelenleg a daganatszürésnek sincsen patológiai/citológiai TVK-ja.

\footnotetext{
${ }^{5}$ GINOP - Gazdaságfejlesztési és Innovációs Operatív Program.

${ }^{6}$ VEKOP - Versenyképes Közép-Magyarország Operatív Program.
} 
Végül egy újabb keletủ probléma az, hogy a molekuláris patológiai diagnosztika, különösen annak terápiás célú része is TVK alatt áll az ún. $\mathrm{PCR}^{7}$ - (molekuláris diagnosztikai vizsgálatok) kasszán keresztül, holott a korszerü és nagyon drága új onkológiai gyógyszerek alkalmazásának elengedhetetlen feltétele az ilyen diagnosztika elvégzése, tehát itt sem értelmezhető a TVK. Csak a teljesség kedvéért: ez utóbbi terápiához kötött molekuláris patológiai szolgáltatások minimális finanszírozásának igénye 1,2 milliárd forint, aminek csak a töredéke áll jelenleg rendelkezésre.

\section{A HAZAI PATOLÓGIAI KUTATÁSOK JELENTŐSÉGE, PATOLÓGUS KUTATÓK}

A négy orvosegyetem és az Országos Onkológiai Intézet a hazai patológiai kutatások központjai, melyekben száz patológus szakorvos dolgozik, a hazai patológusok 40\%-a (2. táblázat). Az itt dolgozó patológusok több mint $60 \%$-a minősített, a minősítettek aránya a Semmelweis Egyetem 1. számú Patológiai és Kísérleti Rákkutató Intézetében és a Szegedi Tudományegyetem Patológiai Intézetében a legmagasabb. A Semmelweis Egyetem patológiai intézeteiben magas az MTA doktora címmel rendelkezők száma, és itt dolgozik egy-egy MTA-tag patológus is. Ugyanakkor a nem egyetemi patológiai osztályokon a minősített patológusok aránya alacsony, és annak az elvnek sem lehet az esetek többségében megfelelni, hogy a patológiai osztályokat minősített patológus vezesse. Ez alól az országos intézetek kivételt képeznek. A magyar patológiának tizennyolc egyetemi tanára van, akik döntö többsége a Semmelweis Egyetemen dolgozik és tanít.

2. táblázat. Minősített patológusok a patológiai centrumokban

\begin{tabular}{|c|c|c|c|c|c|c|c|}
\hline & 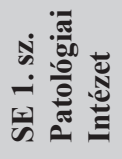 & 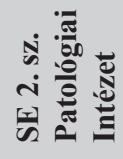 & 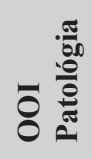 & 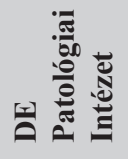 & 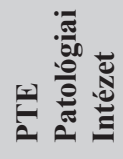 & 四 & 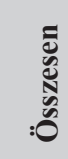 \\
\hline Szakorvos & 24 & 20 & 19 & 17 & 15 & 13 & 108 \\
\hline $\mathrm{PhD}$ & 16 & 8 & 3 & 7 & 5 & 8 & 47 \\
\hline MTA doktora & 5 & 5 & 0 & 3 & 1 & 2 & 16 \\
\hline MTA tagja & 1 & 1 & & & & & 2 \\
\hline Egyetemi tanár & 6 & 6 & & 3 & 1 & 2 & 18 \\
\hline Összes minősített & 22 & 14 & 3 & 10 & 6 & 10 & 65 \\
\hline
\end{tabular}

${ }^{7} \mathrm{PCR}$ - polymerase chain reaction. 
A hazai patológiai kutatások nemzetközileg ismertek, elismertek és meglehetősen sokszínủek. A kísérletes rákkutatás hagyományosan a Semmelweis Egyetem patológiai intézeteihez kötődik, de jelentős az Országos Onkológiai Intézet is ebből a szempontból. Továbbmenve, a Semmelweis Egyetemen nemzetközileg versenyképes májpatológiai és lágyrészdaganat-patológiai kutatások folynak. A hazai hematopatológiai kutatások több egyetemen is nemzetközi jelentőségüek (a Semmelweis Egyetem, a Pécsi Tudományegyetem és a Debreceni Egyetem patológiai intézeteiben). Hasonlóan kiemelkedő színvonalú emlőpatológiai kutatások folynak a Semmelweis Egyetem és a Szegedi Tudományegyetem patológiai intézeteiben. Nagy a jelentősége annak, hogy nemzetközi színvonalú tüdőrák-patológiai kutatások zajlanak a Semmelweis Egyetem patológiai intézeteiben és az Országos Korányi Pulmonológiai Intézetben. Kiemelkedő színvonalú neuropatológiai kutatások köthetök a Debreceni Egyetem, illetve most már a Szegedi Tudományegyetem Patológiai Intézetéhez. Végül, de nem utolsósorban, nemzetközi színvonalúak a hazai melanómapatológiai kutatások a Semmelweis Egyetemen, az Országos Onkológiai Intézetben, a Debreceni Egyetem Megelőző Orvostani Intézetében és a Szegedi Tudományegyetem Bőrgyógyászati Klinikáján. Ezen kutatások főbb eredményeiről 2015-ben a Magyar Onkológiában jelent meg összefoglaló (Balázs et al., 2015). Ezeket a kutatásokat számos OTKA-pályázat, de ami ennél fontosabb, több $\mathrm{NVKP}^{8}$-pályázat is támogatja. A kutatások színvonalát mi sem jellemzi jobban, mint hogy 2016-2017-ben ezek eredményeként a négy orvosegyetem patológiai intézetei az MTMT $^{9}$ adatbázisa alapján 57, ún. Q1-es minősítésű és 54 D1-es minősítésủ nemzetközi közlemény jelentettek meg.

Nemzetközi jelentőségü, hogy a digitális patológia fejlesztésére a Semmelweis Egyetemen valaha $\mathrm{KKV}^{10}$-ként létrejött 3D-Histech Kft. mára igazi nemzetközi szereplővé nőtte ki magát az eszközök fejlesztésében és forgalmazásában, aminek mintegy mellékhatásaként számos hazai patológiai centrum is bekapcsolódhatott a fejlesztésekbe és kutatásokba. A cég digitális metszetszkennereket, szöveti mikrosorozatkészítő berendezéseket, immunfestő automatákat, valamint képanalizáló programokat és patológiai laboratóriumi informatikai rendszereket fejleszt és forgalmaz. Sajnálatos, hogy ennek ellenére a hazai patológiai osztályokon ezen berendezéseknek és programoknak csak egy töredéke található meg.

A hazai patológusok nemzetközi ismertségét és elismertségét mi sem jellemzi jobban, mint hogy az Európai Patológus Társaság vezetőségének van magyar tagja, illetve annak két munkacsoportjában (emlőrák- és molekuláris patológia) is dolgoznak magyar tagok. Hasonlóan jelentős, hogy a Confederation of European Neuropathological Societiesben is van magyar vezetőségi tag. Az európai patoló-

\footnotetext{
${ }^{8} \mathrm{NVKP}$ - Nemzeti versenyképességi és kiválósági program.

${ }^{9}$ MTMT - Magyar Tudományos Művek Tára.

${ }^{10} \mathrm{KKV}$ - kis- és középvállalkozások.
} 
gus szakképzési irányelvekért felelős UEMS ${ }^{11}$-szervezetben is több magyar patológus dolgozik. Meggyőződésem, hogy annak is nagy a jelentősége, hogy a mintegy tíz éve létrejött közép-európai tüdőrák munkacsoportnak is vannak hazai patológus tagjai. Végül igen jelentős tény, hogy a hazai patológia eredményeinek nemzetközi megismertetésére huszonöt éve megalapították a Pathology Oncology Research címü, angol nyelvü folyóiratot, amely mára egy elismert, Q2-besorolású, nemzetközi folyóirat lett magyar főszerkesztőkkel és itthoni szerkesztőbizottsággal, melyben a megjelenő közlemények 10-15\%-a mind a mai napig hazai.

\section{A HAZAI PATOLÓGIA FEJLESZTÉSE, LEHETSÉGES IRÁNYOK}

A jelenlegi szakorvos-ellátottság alapján a kialakult helyzeten nehéz javítani. Sokszor elhangzik, hogy a magánszolgáltatók segítségével megoldható a jelenlegi probléma. Azt viszont tudni kell, hogy ezzel nem lesz több patológus, csak a patológusokra eső terhek máshogy oszlanak meg, és szerencsés esetben magasabb jövedelemre tehetnek szert. Újra és újra felmerül, hogy centralizálni kell a patológiai szolgáltatásokat, hogy a rendelkezésre álló szakorvosokat és infrastruktúrát optimálisabban lehessen kihasználni. Ebben az esetben a javasolt modell: a már jelenleg is müködő hat III. szintü centrum és tizenöt-húsz patológiai osztály. Ebben a koncepcióban azonban figyelembe kell venni, hogy jelenleg Magyarországon harminchárom onkológiai osztály müködik, és számos kórház folytat daganatsebészetet, amelyeknek kisebb-nagyobb mértékben „sürgősségi”, helyi, illetve patológiai szolgáltatásra van szükségük. Mint korábban bemutattuk, a patológiai osztályok mintegy 40\%-a ún. egyszemélyes patológia, ahol a patológus magára hagyva, konzultációs segítség nélkül próbálja megoldani a napi feladatait. Az ilyen helyzeteken Európában a digitális patológiai hálózatok kialakításával igyekeztek segíteni, ami hazánkban is egy valós opció, különösen annak figyelembevételével, hogy van hazai fejlesztö/gyártó szereplö. Kidolgozásra került egy pilotprogram, amelyet a Norvég Alap támogat. A program gyakorlatilag egy megvalósíthatósági tanulmány elkészítése. Jellemző, hogy amíg hazánkban egy ilyen programnak csak a kidolgozása zajlik, addig egész országok valósítottak meg ehhez nagyon hasonló fejlesztési programokat a közelmúltban.

A ,patológia-beteg" tartós gyógyulása azonban ettől nem várható. A legszükebb keresztmetszet az égető hazai szakemberhiány, ennek kezelése a patológus rezidensek számának jelentős és tartós emelésén alapulhat, ami hosszú távon lassan, de jelentősen megemeli a szakorvosok számát. Az átmeneti periódusra mindemellett ki kell dolgozni egy brain-drain-back típusú programot a külföldön dolgozó patológus szakemberek visszahívására, aminek feltétele a fizetések

\footnotetext{
${ }^{11}$ UEMS - Union Européenne des Médecins Spécialistes.
} 
megemelése és vonzó infrastrukturális és finanszírozási környezet kialakítása. Felmerülhet, hogy a jelenlegi szakemberekre nehezedő terheket a munka menynyiségének csökkentésével, illetve átcsoportosításával is el lehetne érni, ami a kórboncolásokra vonatkozó szabályok átgondolását érintené. A TVK-mentes kórboncolás elve a végső diagnózisok és a halálozási statisztikák pontosítását helyezi előtérbe, és nem veszi figyelembe, hogy az egészségügyi rendszer folyamatosan rengeteget fordít az in vivo diagnosztika fejlesztésére. Ennek eredménye mindenképpen jobban kivizsgált betegségeket és pontosabb mutatókat kell hogy jelentsen, ami elvileg a kórboncolások jelentős részének kiváltását tenné lehetővé. Napjainkra a kórboncolás társadalmi elfogadottsága erősen visszaszorult, és az esetek jelentős részében a családtagok értetlenül állnak a szigorú törvényi előírás előtt. A kórboncolás elrendelésének folyamata ráadásul olyan külső szabályozókat tartalmaz (például: éjszakai ügyelet, tisztiorvosi hivatal véleménye), ami nem tesz lehetővé felelős, valamennyi szempont figyelembevételével megalapozott patológusi döntéshozatalt. A szakmai feladat ellátása helyett ezért sok esetben lényegében a rendelet végrehajtása történik, mely tevékenység a szaporodó diagnosztikus kihívásoktól von el kapacitást.

A hazai patológia megítélése és helyzete Janus-arcú. Ha a kórházak patológiai szolgáltatásainak mennyiségét és minőségét tekintjük, látható hogy ezeket számos objektív tényező negatívan befolyásolja, aminek eredője egy lassú és nem kellő színvonalú diagnosztika. Ugyanakkor a nagy patológiai centrumok nemzetközi színvonalon igyekeznek dolgozni, és jelentős kutatás-fejlesztési eredményeket értek és érnek el, annak ellenére, hogy a szolgáltatás finanszírozása nem megfelelö, és a kutatási források sem túlságosan bőségesek. A patológia betegellátásban betöltött szerepe alapján kiemelkedö jelentőségü diagnosztikus modalitás. Helyzetének és finanszírozásának javításával az abba fektetett tőke sokszorosan megtérülne a teljes betegellátási láncolatban.

\section{IRODALOM}

Balázs M. - Vízkeleti L. - Ecsedi Sz. et al. (2015): Hazai melanomakutatások: reményt keltő eredmények egy korábban reménytelen daganatban. Magyar Onkológia, 59, 4, 275-281. 